\section{Response to Immunization with Haemophilus influenzae Type b Polysaccharide-Pertussis Vaccine and Risk of Haemophilus Meningitis in Children with the $\mathrm{Km}(1)$ Immunoglobulin Allotype}

Dan M. Granoff, Janardan P. Pandey, Eyla Boies, Janet Squires, Robert S. Munson, Jr., and Brian Suarez Departments of Pediatrics, Genetics, and Psychiatry, Washington University School of Medicine; Division of Infectious Diseases, St. Louis Children's Hospital, St. Louis, Missouri 63178; and the Department of Basic and Clinical Immunology, Medical University of South Carolina, Charleston, South Carolina 29425 bstract. In experimental animals, immune responses to certain antigens are regulated by immunoglobulin allotype-linked genes. In an effort to detect such genes in humans, we examined the antibody responses of 74 healthy children with different $\mathrm{Km}(1)$ or $\mathrm{Gm}(23)$ allotypes to a Haemophilus influenzae type b vaccine (type $b$ polysaccharide capsule-pertussis vaccine). The anticapsular antibody responses of black or white children with the $\mathrm{Km}(1)$ allotype were 4.6 - to 9.5 -fold higher than those of children who lacked this determinant $(P<0.004)$. No significant differences were found in antibody response with respect to the $\mathrm{Gm}(23)$ allotype. The frequencies of $\mathrm{Km}(1)$ and $\mathrm{Gm}(23)$ also were examined in 170 patients with Haemophilus meningitis, 71 patients with epiglottitis, and 173 control children. $\mathrm{Km}(1)$ was detected less frequently in black patients with meningitis (38\%) than in those with epiglottitis (81\%, $P<0.002)$ or in controls $(66 \%, P<0.0007)$. The relative risk of meningitis thus was 3.2 -fold lower among black children with the $\mathrm{Km}(1)$ allotype than in those who lacked this allotype (odds ratio $=0.3,95 \%$ confidence interval 0.2 to 0.6 ). However, the risk of meningitis was not decreased in white children with the $\mathrm{Km}(1)$ allotype (odds ratio $=1.0$ ). There were no significant differences in the frequency of $\mathrm{Gm}(23)$ among the patient groups and controls. The $\mathrm{Km}(1)$ allotype but

Received for publication 12 April 1984 and in revised form 26 June 1984.

J. Clin. Invest.

(c) The American Society for Clinical Investigation, Inc. 0021-9738/84/11/1708/07 $\$ 1.00$

Volume 74, November 1984, 1708-1714 not the $\mathrm{Gm}(23)$ thus defines a subpopulation of children of both races who are high responders to this vaccine, and black children but not white children with the $\mathrm{Km}$ (1) allotype are at decreased risk of developing Haemophilus meningitis. These data indicate that in blacks, genes associated with $\mathrm{Km}(1)$ may affect immune response to a prototype type $\mathrm{b}$ Haemophilus vaccine, and perhaps interact with another factor related to race to affect susceptibility to Haemophilus meningitis.

\section{Introduction}

Haemophilus influenzae type $\mathrm{b}$ is the most common cause of bacterial meningitis in children in North America (1). This organism also is an important cause of other serious infections such as acute epiglottitis. Socioeconomic status, environment, and racial factors have been found to affect the incidence of invasive Haemophilus disease in different populations (1-4). Recent evidence also suggests that genetic factors may influence susceptibility $(2,5-7)$.

Considerable evidence from studies of inbred strains of mice indicates that immune responsiveness is under genetic control (for examples, see references 8 and 9). A large number of immune response genes have been described in laboratory animals. The majority are linked to the major histocompatibility complex $(8,9)$. However, studies indicate that genes associated with immunoglobulin allotype determinants also may affect the antibody responses to certain antigens (10-13). Allotypes are hereditary antigenic determinants on Ig molecules found in some but not all individuals of a species (14). They are inherited in a Mendelian fashion and are codominant (i.e., both allelic genes are expressed in a heterozygote).

In humans, $\mathrm{Gm}$ allotype specificities are located on the constant region of the $\gamma$-heavy chain. Thus far, $25 \mathrm{Gm}$ specificities have been detected. Three other allotype markers, 
the $\mathrm{Km}$ factors, have been correlated with amino acid substitutions in the constant region of the $\kappa$-chain (14). The gene loci for $\mathrm{Km}$ and $\mathrm{Gm}$ specificities are not linked (they are located on different chromosomes). Two allotypes, $\mathrm{Km}(1)$ and $\mathrm{Gm}(23)$ (also designated as $\mathrm{G} 2 \mathrm{~m}$ [15]) (the latter, a specificity on $\mathrm{IgG}_{2}$ subclass molecules), have been associated with altered immune responses to the capsular polysaccharide of $H$. influenzae type b $(15,16)$ and to other bacterial antigens $(17,18)$. Further, a recent preliminary report suggests that subjects with $\operatorname{Gm}(23)$ have a lower relative risk of developing invasive Haemophilus disease than those who lack this determinant (19).

The capsular polysaccharide of $H$. influenzae type b (a polymer of $\rightarrow 3)-\beta$-D-Ribf- $(1 \rightarrow 1)$-ribitol-5-(phosphate $\rightarrow$ ) $(19 a)$ is an important virulence determinant $(20,21)$. Nearly all invasive Haemophilus disease in children is caused by type $b$ organisms (1-3), and organisms that have lost their capsule are no longer pathogenic in experimental animals $(20,21)$. Furthermore, antibody against the type b capsule confers protection against invasive Haemophilus disease (22-24). Preliminary data also suggest that this antibody is predominantly of the $\mathrm{IgG}_{2}$ subclass (25) and is of restricted heterogeneity with respect to kappa/lambda light chain and clonatype distribution (26). It seemed possible that genes in linkage disequilibrium with those coding for $\mathrm{Km}(1)$ or $\mathrm{Gm}(23)$ allotypes might affect immunologic responses to the type $b$ capsule, and thereby influence susceptibility to different manifestations of type $b$ Haemophilus infection. This study, therefore, was designed to address the following questions: $(a)$ Do genes associated with the $\mathrm{Km}(1)$ or $\mathrm{Gm}(23)$ allotypes affect immune responsiveness to an $H$. influenzae type b vaccine; $(b)$ Do children with the $\mathrm{Km}(1)$ or $\mathrm{Gm}(23)$ allotypes have a different risk of developing Haemophilus meningitis or epiglottitis than children who lack these allotypes?

\section{Methods}

Comparison of the frequency of $\mathrm{Km}(1)$ or $\mathrm{Gm}(23)$ in patients and controls is described as follows.

Subject selection. Serum samples were obtained from 241 patients ( 87 blacks and 154 whites) with $H$. influenzae type b meningitis or epiglottitis confirmed by positive cultures of blood or cerebrospinal fluid, or by detection of capsular antigen in cerebrospinal fluid, serum, or urine by countercurrent immunoelectrophoresis. 170 patients had meningitis and 71 had epiglottitis. All of the patients resided in the greater St. Louis metropolitan area and had been hospitalized at either St. Louis Children's Hospital or Cardinal Glennon Memorial Hospital for Children. Serum samples also were obtained from 173 control children ( 83 blacks and 90 whites) without a history of type b Haemophilus disease. These subjects also resided in the greater St. Louis area and were volunteers in vaccine trials conducted by our group. The control children were recruited from several sources: a prepaid medical care group associated with Washington University, an unaffiliated family practice clinic in a local community hospital, and two private practices serving primarily families of low income. Patients and control individuals $<7$ mo of age were excluded from this study because in this age group the presence of small amounts of maternal antibody can interfere with determination of Ig allotypes. The frequencies of different HLA A, B, and DR specificities in the white patients and controls have been reported (6).

Response to immunization. 56 of the control children from St. Louis, MO ( 21 blacks and 35 whites), and 18 additional white children from Danbury, CT were immunized. Serum samples from the children in Connecticut were kindly provided by Dr. Martha Lepow, Albany Medical College, Albany, NY. The children ranged in age from 9 to 30 mo (mean $\pm \mathrm{SD}=18.6 \pm 5.7$ ). 25 of the children from St. Louis served as controls in a previous study and their antibody responses have been reported (7). A $0.5-\mathrm{ml}$ dose containing $10 \mu \mathrm{g}$ of the type b capsular polysaccharide and four opacity units of pertussis vaccine (PRP-pertussis vaccine) was administered intramuscularly. The vaccine (lots 7-1374-016A, 026A, and 039A) was supplied by Lederle Laboratories (Division of American Cyanamid Co., Pearl River, NY). Characterization of the vaccine (27) and its immunogenicity in laboratory animals $(27,28)$ and humans $(7,29-32)$ have been reported. Blood samples were obtained by venipuncture before immunization and 4 to 6 wk later. Serum antibody concentrations against the type b capsular antigen were measured by a modified Farr radioantigen binding assay using ${ }^{3} \mathrm{H}$-labeled type $b$ polysaccharide antigen (33). The minimum amount of antibody detectable in this assay was $25 \mathrm{ng}$ antibody protein per milliliter of serum, as determined by dilutions of $\boldsymbol{H}$. influenzae type b human reference serum (SK) (34). The correlation coefficient between values obtained on serum samples assayed on different days was $>0.90$.

IgG and IgM anti-PRP antibody were measured by an enzymelinked immunosorbent assay using type b capsule-tyramine as described (7). Alkaline phosphatase conjugated goat anti-human IgG or IgM (heavy chain specific, Sigma Chemical Co., St. Louis, MO) were used for Ig detection. Titers were determined graphically as the reciprocal of the serum dilution producing an absorbence of 0.3 as described. For IgG the assay was considered complete when wells containing a 1:5,000 dilution of a standard human serum containing $35 \mu \mathrm{g} / \mathrm{ml}$ of anticapsular antibody reached an absorbence of 0.3. For IgM, a 1:300 dilution of a serum containing $6.6 \mu \mathrm{g} / \mathrm{ml}$ was used. In previous studies, replicate values obtained in assays performed on different days agreed within a onefold dilution in $90 \%$ of samples (7).

Total IgG and IgM concentrations were measured in serum samples obtained prior to immunization from the 56 children in St. Louis using the technique of radial immunodiffusion (ICL Scientific, Fountain Valley, CA).

The $\mathrm{Km}(1)$ and $\mathrm{Gm}(23)$ immunoglobulin allotypes were measured using techniques of hemagglutination inhibition using reagents and methods that have been described in detail $(35,36)$. The assays were performed on serum samples that had been stored frozen at $-70^{\circ}$. The serum samples were coded and the clinical status of the subjects was not known to the technician or investigator.

Statistical analysis. Statistical analysis was performed using SPSS software (37) on a Harris 500 computer (Harris Corp., Melbourne, $\mathrm{FL})$. The frequencies of the $\mathrm{Km}(1)$ or $\mathrm{Gm}(23)$ allotypes among the patients and controls were compared using the chi-square test. Odds ratios and $95 \%$ confidence intervals were calculated according to the method described by Haldane (38). A $t$ test for unpaired samples was used to compare the geometric mean concentrations of antibody in vaccinees grouped according to $\mathrm{Km}(1)$ or $\mathrm{Gm}(23)$ immunoglobulin allotype status. Age is correlated with immune response to the type $b$ polysaccharide (24). Because subjects with different allotypes were not individually matched for age, covariance analysis of the group data was used. Accordingly, differences in group geometric means [e.g., 
between $K m(1)$ positive vs. $K m(1)$ negative children] were tested by statistically removing the linear effect of age (the covariate). This is equivalent to testing for a difference in means of residuals. The residuals are the difference of the actual immune response values and a regression quantity based on the associated age variable (39).

\section{Results}

$K m(1)$ allotype and response to immunization. In a previous report the antibody responses of infants from Jamaica immunized with type b polysaccharide-pertussis vaccine were examined (29). In a pilot study for the present work, we measured $\mathrm{Km}(1)$ allotypes in serum samples remaining from nine black Jamaican infants who had been immunized at 2, 4 , and 6 mo of age. (Serum samples from the children in Jamaica were kindly provided by Christine Williams, MD, Lederle Laboratories, Pearl River, NY.) As shown in Table I, we found that children with $\mathrm{Km}(1)$ allotype had sixfold higher anticapsular antibody concentrations one month after the third injection of vaccine compared with the responses of those who lacked this allotype. This difference was not statistically significant $(P=0.09)$ but the sample size was small and the statistical power to detect a difference was limited. The data were sufficient to stimulate us to examine this same question in a larger group of children immunized with this vaccine in the United States. Therefore, we determined $\mathrm{Km}(1)$ and $\mathrm{Gm}(23)$ allotypes in children 9-30 mo of age living in St. Louis, MO, or Danbury, CT, who had received one injection of vaccine (Table I). We found that there were no significant differences in the serum concentrations of antibody before immunization between children who were $\mathrm{Km}(1)$ positive and those who were $\mathrm{Km}(1)$ negative. However, $1 \mathrm{mo}$ after immunization, the anticapsular antibody concentrations were 4.6- to 9-fold higher in those with the $\mathrm{Km}(1)$ allotype $(P<0.04$ for black children and $P<0.03$ for white children, analyzed separately; $t$ test). Because of the range in ages of these children, we performed an analysis of covariance in which we removed the effect of age at the time of immunization. The probability values for the main effect due to $\mathrm{Km}(1)$ on response to vaccine were 0.04 for black children, 0.06 for white children, and 0.004 for black and white children analyzed together.

In an effort to characterize further the antibody responses of $\mathrm{Km}(1)$ positive and $\mathrm{Km}(1)$ negative children to type $b$ polysaccharide-pertussis vaccine, we measured class specific antibody against type $b$ capsular polysaccharide in pre- and postimmunization sera from 25 of the subjects from St. Louis who were 9-23 mo of age, using an enzyme-linked immunosorbent assay. We found no significant differences in the IgM anticapsular antibody titers $1 \mathrm{mo}$ after immunization in the seven children with $\mathrm{Km}(1)$ compared with those in 18 children who lacked this allotype $(F=0.5, P=0.5$ by analysis of covariance). However, children with $\mathrm{Km}(1)$ had significantly higher IgG anticapsular antibody responses than those who lacked $\mathrm{Km}(1)(F=10.7, P=0.004$ by similar analysis). The higher anti-capsular antibody responses of children with $\mathrm{Km}(1)$ thus appeared to be primarily IgG and not IgM.

To determine whether the higher antibody responses of children with the $\mathrm{Km}(1)$ allotype reflected higher total concentrations of serum Ig, we also measured the IgG and IgM concentrations in serum obtained before immunization from

Table I. Anticapsular Antibody Responses to PRP-Pertussis Vaccine in Relation to the Km(1) Ig Light Chain Allotype

\begin{tabular}{|c|c|c|c|c|c|c|c|c|}
\hline \multirow[b]{3}{*}{ Population } & \multirow[b]{3}{*}{$\mathrm{Km}(1)$} & \multirow[b]{3}{*}{$\begin{array}{l}\text { Number } \\
\text { tested }\end{array}$} & \multirow[b]{3}{*}{$\begin{array}{l}\text { Mean age } \\
\text { at time } \\
\text { of injection }\end{array}$} & \multicolumn{5}{|c|}{ Serum anticapsular antibody $(\mathrm{ng} / \mathrm{ml})$} \\
\hline & & & & \multicolumn{2}{|c|}{ Preimmunization } & \multicolumn{3}{|l|}{ Post (1 mo) } \\
\hline & & & & Geo mean & $\begin{array}{l}\text { Mean } \\
\log _{10} \pm S D\end{array}$ & Geo mean & $\begin{array}{l}\text { Mean } \\
\log _{10} \pm S D\end{array}$ & $P^{*}$ \\
\hline & & & mo & & & & & \\
\hline \multirow{2}{*}{$\begin{array}{l}\text { Blacks, Jamaica, } \\
\text { West Indies }\end{array}$} & + & 4 & 6 & 110 & $2.04 \pm 0.65$ & 2,161 & $3.34 \pm 0.14$ & \multirow{2}{*}{0.09} \\
\hline & - & 5 & 6 & 168 & $2.36 \pm 0.32$ & 358 & $2.55 \pm 0.41$ & \\
\hline \multirow[t]{2}{*}{ Blacks, St. Louis, MO§ } & + & 13 & 22 & 109 & $2.04 \pm 0.51$ & 1,702 & $3.23 \pm 0.66$ & \multirow{2}{*}{$<0.04$} \\
\hline & - & 8 & 21 & 64 & $1.80 \pm 0.45$ & 366 & $2.56 \pm 0.61$ & \\
\hline \multirow{2}{*}{$\begin{array}{c}\text { Whites, St. Louis, MO } \\
\text { and Danbury, CT§ }\end{array}$} & + & 5 & 20 & 71 & $1.85 \pm 0.53$ & 5,176 & $3.72 \pm 0.53$ & \multirow{2}{*}{$<0.03$} \\
\hline & - & 48 & 17 & 95 & $1.98 \pm 0.82$ & 543 & $2.73 \pm 0.96$ & \\
\hline
\end{tabular}

* There were no significant differences in the antibody concentrations prior to immunization with respect to $\mathrm{Km}(1)$ allotype. The probabilities of the differences in the geometric mean antibody concentrations observed after immunization were calculated by a $t$ test (two-tailed). Analysis of covariance was also performed on the data from blacks in St. Louis and from all white subjects to remove the effect of age. The probability values for the main effect due to $\mathrm{Km}(1)$ on antibody response were $P=0.04$ for blacks, $P=0.06$ for whites, and $P<0.004$ for blacks and whites combined. $\ddagger$ Immunization at 2,4 , and 6 mo of age. Neither $\mathrm{Km}(1)+$ or $\mathrm{Km}(1)-$ infants responded to the first two injections. For our analysis, antibody was measured in serum obtained prior to the last injection and 1 mo later. § Immunization once at 9-30 mo of age. Serum obtained for antibody before immunization and 1 mo later. 
the 56 vaccinees in St. Louis. As shown in Table II, no significant differences were found when the mean serum $\mathrm{Ig}$ concentrations were compared between children with $\mathrm{Km}(1)$ and those who lacked this allotype.

$G m(23)$ allotype and response to immunization. The antibody responses of the white children from St. Louis and Danbury also were analyzed in relation to $\mathrm{Gm}(23)$. (Black children were excluded because, as expected, only one of the black vaccinees was positive for this marker.) There were 27 white children who were $\operatorname{Gm}(23)$ positive and 26 who were $\operatorname{Gm}(23)$ negative. The mean ages of the two groups were 18.5 and $16.6 \mathrm{mo}$, respectively $(P>0.4)$. There were no significant differences between the anticapsular antibody responses to immunization of the two groups (geometric mean serum antiPRP antibody concentrations 1 mo after immunization of 1,005 and 444 , respectively, $P=0.2$ by $t$ test, or $P=0.4$ by analysis of covariance with age as a covariate).

Frequency of $\mathrm{Km}(1)$ or $\mathrm{Gm}(23)$ in patients with Haemophilus disease. As summarized in Table III, $\mathrm{Km}(1)$ was detected in only $38 \%$ of black patients with Haemophilus meningitis but in $81 \%$ of those with epiglottitis $\left(\chi^{2}=9.94, P<0.002\right)$ and $66 \%$ of black control subjects $\left(\chi^{2}=11.4, P<0.0007\right.$, when compared with that in patients with meningitis). Black children with $\mathrm{Km}(1)$ had a 3.2-fold lower relative risk of developing meningitis than those who lacked this allotype (odds ratio $=0.32,95 \%$ confidence interval 0.3 to 0.6 ). However, blacks with $\mathrm{Km}(1)$ did not have a lower risk of epiglottitis (odds ratio $=2.0,95 \%$ confidence interval 0.6 to 6.2 ). In contrast to blacks, the risk of meningitis was not decreased in white subjects with the $\mathrm{Km}(1)$ allotype (Table III).

There were no significant differences in the frequency of $\mathrm{Gm}(23)$ among patients with meningitis, epiglottitis, or controls (for blacks: 11, 11, and 13\%, respectively; for whites: 73,70 , and $66 \%$, respectively; $P>0.5$ ).

\section{Discussion}

The purified type $b$ polysaccharide is a poor immunogen in children $<18-23$ mo of age (24). In this study, we used a

Table II. Serum Immunoglobulin Concentrations in Relation to the Km(1) Allotype

\begin{tabular}{|c|c|c|c|c|c|}
\hline \multirow[b]{2}{*}{$\mathrm{Km}(1)$} & \multirow{2}{*}{$\begin{array}{l}\text { Number } \\
\text { tested* }\end{array}$} & \multirow{2}{*}{$\begin{array}{l}\text { Mean } \\
\text { age }\end{array}$} & \multicolumn{3}{|c|}{ Ig concentrations $\pm S D$} \\
\hline & & & IgM & IgG & $P$ \\
\hline & & mo & $m g / d l$ & $m g / d l$ & \\
\hline+ & 17 & 21.4 & $207 \pm 92$ & $1082 \pm 317$ & NSł \\
\hline- & 39 & 18.3 & $202 \pm 80$ & $920 \pm 353$ & NS \\
\hline
\end{tabular}

* Includes all vaccinees from St. Louis $(n=56)$. Data from blacks and whites are combined.

$\ddagger$ NS, not significant $(P>0.05$ by $t$ test and by analysis of covariance with age as covariate).
Table III. Frequency of $\mathrm{Km}(\mathrm{I})$ Immunoglobulin Allotype in Patients with Haemophilus

Influenzae Type b Meningitis or Epiglottitis

\begin{tabular}{llllll}
\hline & $\begin{array}{l}\text { Number } \\
\text { tested }\end{array}$ & $\begin{array}{l}\text { Number } \\
\text { with Km(1) }\end{array}$ & $\begin{array}{l}\text { Odds- } \\
\text { ratio }\end{array}$ & $\chi^{2}$ & $P^{*}$ \\
\hline Blacks & & $\%$ & & & \\
Meningitis & 66 & $25(38)$ & 0.3 & 11.4 & $<0.0007$ \\
Epiglottitis & 21 & $17(81)$ & 2.0 & 1.4 & NS \\
Controls & 83 & $55(66)$ & - & - & - \\
Whites & & & & & \\
Meningitis & 104 & $19(18)$ & 1.0 & 0.1 & NS \\
Epiglottitis & 50 & $10(20)$ & 1.2 & 0.1 & NS \\
Controls & 90 & $16(18)$ & - & - & - \\
& & & & & \\
\hline
\end{tabular}

* Compared with frequency of $\mathrm{Km}(1)$ in corresponding control group. $\chi^{2}$ $=9.94$ (Haldane correction for small sample size), $P<0.002$, comparing frequency of $\mathrm{Km}(1)$ in patients with meningitis with that in patients with epiglottitis.

$\ddagger$ NS, not significant $(P>0.05)$.

vaccine consisting of the type $b$ polysaccharide mixed with pertussis vaccine (27). This vaccine is immunogenic in rats $(27,28)$, a species that does not respond to the purified polysaccharide. This vaccine also is immunogenic in most human infants 12-23 mo of age $(7,29,30)$, an age group highly susceptible to type b Haemophilus disease (1-3). In the present study, $77 \%$ of children given the combined vaccine produced antibody, including in many, IgG. This high rate of response permitted analysis of the subjects' responses in relation to the presence or absence of the $\mathrm{Km}(1)$ or $\mathrm{Gm}(23)$ allotypes.

We found that both black and white children who had the Ig light chain allotype, $\mathrm{Km}(1)$, developed higher antibody responses to the type $b$ polysaccharide after immunization with this preparation than did children who lacked $\mathrm{Km}(1)$. The higher responses reflected different IgG anticapsular antibody responses; the $\operatorname{IgM}$ responses of $\mathrm{Km}(1)$ positive and negative children were not significantly different.

Although our data do not address the mechanism of the higher responses of the children with $\mathrm{Km}(1)$, two other studies provide information suggesting that the higher responses may not be capsular antigen specific, but instead be modulated by different genetically regulated responses to the adjuvant (15, 17). In a study of the responses to a polysaccharide vaccine administered with an adjuvant (group B meningococcal polysaccharide "complexed" with an outer membrane protein), adults with the $\mathrm{Km}(1)$ allotype had higher antipolysaccharide antibody responses than those who lacked $\mathrm{Km}(1)$ (17). As in the present study, this finding was present in both blacks and whites. In contrast, in a preliminary study of children immunized with the purified type b Haemophilus polysaccharide, lower anticapsular antibody responses were present among white children with $\mathrm{Km}(1)$ compared with those who lacked $\mathrm{Km}(1)$ (16). (In this latter study, no differences in response 
were observed with respect to $\mathrm{Km}$ [1] among black children, but there were too few black children of either allotype who responded to vaccine to permit an appropriate analysis.)

Antibody responses to many bacterial polysaccharide antigens are thought to be thymic independent $(40,41)$. In humans, both IgM and IgG responses to polysaccharide antigens are observed $(23,42)$ but it appears that the $\operatorname{IgG}$ responses may preferentially involve the $\mathrm{IgG}_{2}$ subclass (25). Siber et al. (43) have provided data that the serum pool size of $\mathrm{IgG}_{2}$ in an individual may be an important determinant of the magnitude of the antibody response to certain bacterial polysaccharides, including the type b capsule of Haemophilus (43). Therefore, we measured $\mathrm{IgG}_{2}$ concentrations in serum samples obtained before immunization from the subjects in this trial (44), using a sensitive and specific inhibition radioimmunoassay (45). Anticapsular antibody responses to vaccine were found to correlate with serum $\operatorname{IgG}_{2}$ concentrations $(r=0.3, P$ $<0.02)$. However, after correction for age, this variable $\left(\mathrm{IgG}_{2}\right)$ no longer contributed significantly $(P>0.10)$. Thus, although $\mathrm{IgG}_{2}$ pool size may contribute, its effect appears to be confounded with age.

In the United States, black children have a three- to fivefold higher risk of developing Haemophilus meningitis than white children (1-3). The present data suggest that the risk of developing Haemophilus meningitis among blacks is not uniform but is higher among the $40-50 \%$ of blacks who lack the $\mathrm{Km}(1)$ allotype (Table III). It should be noted that this finding was not present in whites (Table III). In our study, race was defined by social criteria; that is, subjects were categorized according to the race indicated by their parents. However, from previous studies, many North American blacks have evidence of black-white racial admixture (46). One method to estimate the proportion of genes that are of caucasian origin is to use the $\mathrm{Gm}$ locus, since certain alleles such as $\mathrm{Gm}(2)$, $\mathrm{Gm}(3)$, or $\mathrm{Gm}(21)$ are prevalent in whites but are absent in African blacks (47). It was therefore of interest to compare the frequency of $\mathrm{Km}(1)$ among the black patients and controls after further subdividing them into those with African black Gm phenotypes, i.e., $(1,17 ; 5,13),(1,17 ; 5,6,13)$, or $(1,17 ; 5,6)$ or those with evidence of black-white admixture [presence of $\mathrm{Gm}(2), \mathrm{Gm}(3)$, or $\mathrm{Gm}(21)$ ]. In both groups, the respective frequency of $\mathrm{Km}(1)$ was significantly lower in patients with meningitis than in controls (for black subjects with black African phenotypes, 41 vs. $65 \%$, respectively $\left(\chi^{2}=6.4, P\right.$ $<0.01$ ); for black subjects with $\operatorname{Gm}(2), \operatorname{Gm}(3)$, or $\operatorname{Gm}(21)$, 35 vs. $62 \%$, respectively $\left(\chi^{2}=3.84, P=0.05\right)$. Thus, although the frequency of $\mathrm{Km}(1)$ was similar among white patients with meningitis and controls, it was significantly lower in the black patients with meningitis compared with that in black controls, irrespective of whether the $\mathrm{Gm}$ phenotype of the blacks contained alleles derived from whites.

It has been demonstrated previously that white patients with epiglottitis have different frequencies of certain erythrocyte MNSs antigens than white patients with meningitis $(5,6)$.
Similarly, in the present study, we have shown that black patients with meningitis or epiglottitis differ from each other genetically with respect to the frequency of the $\mathrm{Km}(1)$ allotype (Table III). The fact that this finding was not present in whites in our study suggests that the immunogenetic background of white patients with epiglottitis or meningitis may be different from that of black patients.

We found no significant differences in the frequency of the $\mathrm{Gm}(23)$ allotype among the patient groups and controls, failing to confirm a preliminary report of a lower frequency of this allotype in patients with Haemophilus disease (19). The reason for the discrepant results in the two studies is not evident. Serum samples have been exchanged and there was complete concordance in the results of typing for $\mathrm{Gm}(23)$ between the two laboratories (authors' unpublished observation).

In summary, our data relating magnitude of the antibody response to Haemophilus type b polysaccharide-pertussis vaccine and the $\mathrm{Km}(1)$ allotype provide further evidence supporting genetic regulation of certain immune responses in humans. Furthermore, the lower risk of Haemophilus meningitis found in black children with the $\mathrm{Km}(1)$ allotype also suggests that with an appropriate environmental or genetic background, genes affecting immune responses may function to confer resistance or susceptibility to an infectious agent. One implication of our data is that a vaccine may be immunogenic in the majority of children of susceptible age, but have only limited efficacy in preventing disease in the general population because of failure to confer protection to the subpopulation of children at highest risk of disease because of genetic factors.

\section{Acknowledgments}

We thank Jill Crouse and Karen Beraha, for excellent technical assistance. We are indebted to Lisa M. Dunkle, Cardinal Glennon Memorial Hospital for Children, and Robert Quaas, for assistance in recruitment of patients. J. S.-C. Kuo, Lederle Laboratories, provided ${ }^{3} \mathrm{H}$-labeled type $\mathrm{b}$ capsule and measured anti-capsular antibody in some of the serum samples. Donald J. Krogstad and J. Russell Little, Jr. offered critical comments.

This work was supported by U. S. Public Health Service grants R01 AI 17962 from the National Institute of Allergy and Infectious Diseases, RR-36 from the General Clinical Research Center Branch, and AI 18727, Gm 28067, MH31302, and MH 14677. The clinical vaccine trials were supported by Lederle Laboratories.

\section{References}

1. Fraser, D. W. 1982. Haemophilus influenzae in the community and the home. In Haemophilus influenzae: Epidemiology, Immunology, and Prevention of Disease. S. H. Sell and P. F. Wright, editors. Elsevier Science Publishing Co., Inc., New York, 11-22.

2. Granoff, D. M., and M. Basden. 1980. Haemophilus influenzae infections in Fresno County, California: A prospective study of the effects of age, race, and contact with a case on incidence of disease. $J$. Infect. Dis. 141:40-46.

3. Parke, J. C., Jr., R. Schneerson, and J. B. Robbins. 1972. The 
attack rate, age incidence, racial distribution, and case fatality of Haemophilus influenzae type b meningitis in Mecklenburg County, North Carolina. J. Pediatr. 81:765-769.

4. Granoff, D. M., and R. S. Daum. 1980. Spread of Haemophilus influenzae type b: Recent epidemiologic and therapeutic considerations. J. Pediatr. 97:854-860.

5. Whisnant, J. K., N. Rogentine, M. A. Gralnick, J. J. Schlesselman, and J. B. Robbins. 1976. Host factors and antibody response in Haemophilus influenzae type b meningitis and epiglottitis. J. Infect. Dis. 133:448-455.

6. Granoff, D. M., E. G. Boies, J. E. Squires, J. P. Pandey, B. Suarez, J. Oldfather, and G. Rodey. 1984. HLA and erythrocyte MNSs specificities in patients with Haemophilus influenzae type b meningitis or epiglottitis. J. Infect. Dis. 149:373-377.

7. Granoff, D. M., J. E. Squires, R. S. Munson, Jr., and B. Suarez. 1983. Siblings of patients with Haemophilus meningitis have impaired anticapsular antibody responses to Haemophilus vaccine. J. Pediatr. 103:185-191.

8. Pierce, C. W., S. E. Cullen, J. A. Knapp, B. D. Schwartz, and D. C. Shreffler. 1983. Ir Genes: Past, Present and Future. Humana Press, Clifton, NJ.

9. Benacerraf, B. 1981. Role of MHC gene products in immune regulation. Science (Wash. DC). 212:1229-1238.

10. Morrow, P. R., D. M. Rennick, and E. Benjamini. 1983. The antibody response to a single antigenic determinant of the tobacco mosaic virus protein (TMVP): Effects of allotype-linked genes and restricted heterogeneity of the response. J. Immunol. 131:2875-2881.

11. Eardley, D. D., F. W. Shen, H. Cantor, and R. K. Gershon. 1979. Genetic control of immunoregulatory circuits. Genes linked to the Ig locus govern communication between regulatory T-cell sets. $J$. Exp. Med. 150:44-50.

12. Kagnoff, M. F. 1982. Two genetic loci control the murine immune response to A-gliadin, a wheat protein that activates coeliac sprue. Nature (Lond.). 296:158-160.

13. Hu, S. K., D. O. Eardley, H. Cantor, and R. K. Gershon. 1983. Definition of two pathways for generation of suppressor T-cell activity. Proc. Natl. Acad. Sci. USA. 80:3779-3781.

14. Cazenave, P. A. 1981. Immunoglobulin allotypes. In Lymphocyte Regulation by Antibodies. C. Bona and P. A. Cazenave, editors. John Wiley and Sons, New York. 109-138.

15. Ambrosino, D. M., G. R. Siber, E. van Loghem, and G. Schiffman. 1982. Increased antibody response to immunization with Haemophilus influenzae type $\mathrm{b}$ and pneumococcal capsular polysaccharide vaccines in adults with G2M(n) allotype. Pediatr. Res. 16:234a. (Abstr.)

16. Pandey, J. P., H. H. Fudenberg, G. Virella, C. U. Kyong, C. B. Loadholt, R. M. Galbraith, E. C. Gotschlich, and J. C. Parke, Jr. 1979. Association between immunoglobulin allotypes and immune responses to Haemophilus influenzae and meningococcus polysaccharides. Lancet I:190-192.

17. Pandey, J. P., W. D. Zollinger, H. H. Fudenberg, and C. B. Loadholt. 1981. Immunoglobulin allotypes and immune response to meningococcal group B polysaccharide. J. Clin. Invest. 68:1378-1380.

18. Whittingham, S., J. D. Mathews, M. S. Schanfield, J. F Matthews, B. D. Tait, P. J. Morris, and I. R. Mackay. 1980. Interactive effect of $\mathrm{Gm}$ allotypes and HLA-B locus antigens on the human antibody response to a bacterial antigen. Clin. Exp. Immunol. 40:815.

19. Ambrosino, D. M., G. E. Rosenberg, G. deLange, and G. R.
Siber. 1983. Association of the G2M(N) immunoglobulin allotype with $H$ influenzae type b disease. Twenty-third Interscience Conference on Antimicrobial Agents and Chemotherapy, Las Vegas, 24-26 Oct. 1983. Abstract No. 946.

19a. Crisel, R. M., R. S. Baker, and D. E. Dorman. 1975. Capsular polymer of Haemophilus influenzae, type b. J. Biol. Chem. 250:49264930.

20. Moxon, E. R., and K. A. Vaughn. 1981. The type b capsular polysaccharide as a virulence determinant of Haemophilus influenzae: studies using clinical isolates and laboratory transformants. J. Infect. Dis. 143:517-524.

21. Weller, P. F., A. L. Smith, P. Anderson, and D. H. Smith. 1977. The role of encapsulation and host age in the clearance of Haemophilus influenzae bacteremia. J. Infect. Dis. 135:34-41.

22. Alexander, H. E., M. Heidelberger, and G. Leidy. 1944. The protective or curative element in $H$. influenzae rabbit serum. Yale $J$. Biol. Med. 16:425-434.

23. Schneerson, R., L. P. Rodrigues, J. C. Parke, Jr., and J. B. Robbins. 1971. Immunity to disease caused by Haemophilus influenzae type b. II Specificity and some biologic characteristics of "natural," infection-acquired, and immunization-induced antibodies to the capsular polysaccharide of Haemophilus influenzae type b. J. Immunol. 107:1081-1089.

24. Peltola, H., H. Käyhty, A. Sivonen, and P. H. Mäkelä. 1977. Haemophilus influenzae type b capsular polysaccharide vaccine in children: A double-blind field study of 100,000 vaccinees three months to five years of age in Finland. Pediatrics 60:730-737.

25. Johnston, R. B., Jr., P. Anderson, F. S. Rosen, and D. H. Smith. 1973. Characterization of human antibody to polyribosephosphate, the capsular antigen of Haemophilus influenzae type b. Clin. Immunol. Immunopathol. 1:234-240.

26. Insel, R. A., P. Anderson, M. E. Pichichero, M. S. Amstey, G. Ekborg, and D. H. Smith. Anticapsular antibody to Haemophilus influenzae type b. 1982. In Haemophilus influenzae: Epidemiology, Immunology, and Prevention of Disease. S. H. Sell and P. F. Wright, editors. Elsevier Science Publishing Co., Inc., New York. 155-168.

27. Kuo, J. S.-C. 1980. Combined Haemophilus influenzae type b and pertussis vaccine. United States Government Patent No. 4,196,192.

28. Halsey, N. A., T. L. Johansen, L. C. Bowman, and M. P. Glode. 1983. Evaluation of the protective efficacy of Haemophilus influenzae type $\mathrm{b}$ vaccines in an animal model. Infect. Immun. 39:1196-1200.

29. King, S. D., H. Wynter, A. Ramlal, K. Moodie, D. Castle, J. S.-C. Kuo, L. Barnes, and C. L. Williams, editors. 1981. Safety and immunogenicity of a new Haemophilus influenzae type b vaccine in infants under one year of age. Lancet II:705-709.

30. Pincus, D. J., D. Morrison, C. Andrews, E. Lawrence, S. H. Sell, and P. F. Wright. 1982. Age-related response to two Haemophilus influenzae type b vaccines. J. Pediatr. 100:197-201.

31. Coulehan, J. L., C. Hallowell, R. H. Michaels, T. K. Welty, N. Lui, and J. S.-C. Kuo. 1983. Immunogenicity of a Haemophilus influenzae type $\mathrm{b}$ vaccine in combination with diphtheria-pertussistetanus vaccine in infants. J. Infect. Dis. 148:530-534.

32. Lepow, M. L., G. Peter, M. Glode, R. Daum, R. Michaels, J. Coulehan, N. Lui, and J. Kuo. 1983. Evaluation of three doses of combined diphtheria-pertussis-tetanus $H$. influenzae type b polysaccharide vaccine in infants 2, 4, 6 months of age. Pediatr. Res. 17:275a. (Abstr.)

33. Kuo, J. S.-C., N. Monji, R. S. Schwalbe, and D. W. McCoy. 
1981. A radioactive antigen-binding assay for the measurement of antibody to Haemophilus influenzae type b capsular polysaccharide. J. Immunol. Methods. 43:35-47.

34. Robbins, J. B., J. C. Parke, Jr., R. Schneerson, and J. K. Whisnant. 1973. Quantitative measurement of "natural" and immunization induced Haemophilus influenzae type b antibodies. Pediatr. Res. 7:103-110.

35. Vyas, G. N., H. H. Fudenberg, H. M. Pretty, and E. R. Gold. 1968. A new rapid method for genetic typing of human immunoglobulins. J. Immunol. 100:274-279.

36. Pandey, J. P., B. T. Shannon, M. P. Arala-Chaves, and H. H. Fudenberg. 1982. $\mathrm{Gm}$ and $\mathrm{Km}$ frequencies in a Portugese population. Hum. Genet. 61:154-156.

37. Nie, N. H., C. H. Hull, J. G. Jenkins, K. Steinbrenner, and D. H. Bent. 1975. SPSS: Statistical Package for the Social Sciences, ed 2. McGraw-Hill Book Co., New York. 398-433.

38. Haldane, J. B. S. 1956. The estimation and significance of the logarithm of a ratio of frequencies. Ann. Hum. Genet. 20:309-311.

39. Dixon, W. J., and F. J. Massey. 1969. Introduction to Statistical Analysis, ed. 3, McGraw-Hill, New York. 222-231.

40. Davie, J. M. 1982. Antipolysaccharide immunity in man and animals. In Haemophilus influenzae: Epidemiology, Immunology and Prevention of Disease. S. H. Sell and P. F. Wright, editors. Elsevier Science Publishing Co., Inc., New York. 129-134.
41. Schneerson, R., O. Barrera, A. Sutton, and J. B. Robbins. 1980. Preparation, characterization and immunogenicity of Haemophilus influenzae type b polysaccharide-protein conjugates. J. Exp. Med. 152:361-376.

42. Kayhty, H., R. Schneerson, and A. Sutton. 1983. Class-specific antibody response to Haemophilus influenzae type b capsular polysaccharide vaccine. J. Infect. Dis. 148:767.

43. Siber, G. R., P. H. Schur, A. C. Aisenberg, S. A. Weitzman, and $G$. Schiffman. 1980. Correlation between serum $\operatorname{IgG}_{2}$ concentrations and the antibody response to bacterial polysaccharide antigens. $N$. Engl. J. Med. 303:178-182.

44. Shackelford, P. G., M. N. Nahm, M. G. Scott, S. J. Nelson, and D. M. Granoff. 1983. Serum $\operatorname{IgG}_{2}$ concentrations in normal children: correlation with anti-PRP response to vaccine. Twenty-third Interscience Conference on Antimicrobial Agents and Chemotherapy, Las Vegas, Oct. 24-26 1983. Abstract 949.

45. Perlmutter, R. M., D. Hansburg, D. E. Briles, R. A. Nicoll, and J. M. Davie. 1978. Subclass restriction of murine anticarbohydrate antibodies. J. Immunol. 121:566-572.

46. Reed, T. E. 1969. Critical tests of hypotheses for race mixture using $\mathrm{Gm}$ data on American Caucasians and Negroes. Am. J. Hum. Genet. 21:71-83.

47. Steinberg, A. G., and C. E. Cook. 1981. Distribution of the Human Immunoglobulin Allotypes. Oxford University Press, New York. 1-11. 